\title{
Is Nonterritorial Autonomy Wrong for Indigenous Rights? Examining the 'Territorialisation' of Sami Power in Norway
}

\author{
Aaron John Spitzer \\ Department of Comparative Politics, Universitetet i Bergen, Bergen, Norway \\ aaron.spitzer@uib.no \\ Per Selle \\ Department of Comparative Politics, Universitetet i Bergen, Bergen, Norway \\ per.selle@uib.no
}

\begin{abstract}
Nonterritorial autonomy (NTA) decouples governance of 'people' and 'place', allowing demographically submerged minorities to protect their cultural - but not territorial - interests. Indigenous peoples are often submerged and culturally vulnerable. At the same time, they are often especially interested in protecting the territories that have long sustained them. So, is NTA well-suited or ill-suited for Indigenous self-governance? To explore this, we study Norwegian Sami selfgovernance, an oft-cited case of Indigenous NTA. We make several contributions. We enumerate the variety of Sami-specific rights and powers in Norway, categorising them as either territorial or nonterritorial and tracking their evolution over time. By doing this we reveal that Sami self-governance has recently taken a 'territorial turn'. We explore why this has happened, concluding it is due to the insufficiency of NTA. Finally, we discuss likely limits to further Sami territorialisation.
\end{abstract}

\section{Keywords}

Sami - Indigenous - nonterritorial autonomy - land-claims - territorial authority Norway 
Four decades ago, Western Europe's sole Indigenous people set out to retake control of their culture and homeland. During the unprecedented Alta Conflict, the Sami of Norway protested generations of assimilation, marginalisation, and misuse of their traditional territories. They called for an array of rights and reforms. Some of these were quickly granted, including the establishment of a Sami assembly and powers protecting the Sami language, heritage and economic development. These victories were rightly celebrated. Sami had succeeded in winning back some control of their culture.

But what about control of their homeland? The powers ceded to Norway's Sami in the aftermath of the Alta Conflict were not territorial. This was due, in no small part, to Norwegian ethnogeography - to the fact that, after centuries of colonisation and intermixing, there was almost nowhere in Norway that Sami formed a local majority. Hence the Sami were seen as poorly suited to exercise authority over territory. However, they were felt to be well-suited for an intriguing alternative - 'nonterritorial autonomy', or NTA.

Employed by the Ottomans to empower disparate religious groups, promoted by political thinkers to avert intercultural bloodshed in the lead-up to World War One, and now increasingly used in a variety of multi-ethnic states, NTA aims to provide governing authority to minorities who are thoroughly intertwined with competing peoples. NTA's genius is seen to lie in decoupling the politics of 'people' and 'place'. And indeed, the application of NTA to Norway's Sami has been cited as evidence of this genius. Even more so, Norwegian Sami governance has been cheered as an exemplar of Indigenous NTA, seemingly displaying that Indigenous peoples - being highly culturally vulnerable, dispossessed of land, and numerically overwhelmed - are especially well-suited for NTA.

Other scholars, however, have warned of the shortcomings of NTA, especially for Indigenous peoples. The problem, as they see it, is that NTA fails on the very account that distinguishes Indigenous peoples from other, non-Indigenous minorities. These critics maintain that NTA, by its very nature, does not help Indigenous peoples protect their native environments - the sacrosanct landscapes, waterways, and natural resources that have sustained them for eons.

Who is right? Is NTA well- or ill-suited for Indigenous self-determination? In this article we explore what the Norwegian Sami case can tell us about this question. In doing so, we make several contributions. We enumerate for the first time the variety of Sami-specific rights and powers exercised in Norway, categorising them as territorial or nonterritorial and tracking their evolution 
over time. By doing this, we reveal that Sami self-determination in Norway, despite being lauded as an exemplar of Indigenous NTA, has in fact taken what we call a 'territorial turn'. This turn involves not the creation of a singular Sami territory but rather the institution of a patchwork of Sami rights, powers and authorities over land and natural resources. We explore why this has happened, what it says about the (in)sufficiency of Indigenous NTA, and the prospects for further Sami territorialisation.

We proceed thusly: in the next section we discuss the theory of NTA, its provenance, and the debate concerning its application to Indigenous challenges. We then provide a background on Norway's Sami, tracing their political history from pre-contact times until the Alta Conflict. We go on to explore how the (non)territorial dimension of Sami authority has changed over the past 30 years. Finally, we analyse and conclude.

Theory

Around the world, countless peoples strive to self-govern, not just over their collective affairs but over the places they hold dear. As such, they strive for territorial authority.

Territorial authority is almost inherently zero-sum. To the degree that one group exercises territorial authority, such authority is correspondingly diminished for all other groups. For the purposes of this paper we understand territorial authority to refer to any one of three sorts of powers. ${ }^{1}$ First, territorial authority can mean jurisdiction - i.e., law-making and law-enforcement power over all residents of a given territory. Second, territorial authority can mean collective ownership and/or management of land and resources - land-use planning, development permitting, environmental protection and so forth. Third, territorial authority can mean the power to selectively regulate access, whether geographic (i.e. border control) or access to territorial resources. In any given geographic area these three sorts of territorial powers need not necessarily coincide, nor be exercised by a single authority. Where they do - where a people govern their own state, or province, or autonomous zone - they possess a comprehensive territorial regime.

The aspiration of peoples to exercise territorial authority - and, certainly, to possess a comprehensive territorial regime - is made vexing by a simple fact. There are too few places to go around. We live, as Nimni observes, "in a world

1 A. Stilz, 'Nations, states, and territory', 121:3 Ethics (2011) pp. 572-6o1; M. Moore, A Political Theory of Territory (Oxford University Press, Oxford, 2015) p. 4. 
crowded by states". ${ }^{2}$ At last count there were nearly 200 states, claiming, and often clashing over, all habitable lands on Earth. Left wanting are thousands of minority communities who demand self-determination but lack the option of statehood.

This surfeit of political aspirants and shortage of territory creates a challenge that political thinkers have long struggled to resolve. Certain solutions, which address the problem from the demand side, have rightly fallen out of favour. Genocide, mass deportation, and forced assimilation all reduce territorial claims by eliminating claimants. Liberal democracy seeks to reduce claimants in a different way, by shifting focus from groups to individuals. Meanwhile, other solutions tackle the supply side, manipulating geopolitical space to better accommodate minorities. After the First World War, European borders were redrawn so states and nations would better match up. Where demography and politics allow it, internal borders too may be redrawn, providing federal or other 'compound' governance arrangements to 'nations within'.

But in many cases, demography and politics don't allow borders to be redrawn. In some places, minorities are too intertwined with majorities (or with other minorities) to feasibly rule a space of their own. Or, claimants may prize the same place for contrary purposes, as when hostile faiths battle for Jerusalem, or when industrialists, farmers and hunter-gatherers champion incompatible uses of the commons. And of course, certain minorities were long ago converted into diasporas, with little chance of returning home. In all these cases, self-government requires creative solutions. One such solution is to decouple people and territory. Thus comes the innovation of nonterritorial autonomy (NTA).

\subsection{Non-territorial Autonomy}

NTA is an 'umbrella term'4 associated with various political arrangements that aim to avoid the challenges posed by 'blood and soil' ethnonationalism by dissociating blood from soil. NTA does so by facilitating minority self-government absent geographic authority. Under NTA, internal minorities exercise responsibility not over a place but directly over their cultural members, irrespective of where they live. In this way, NTA is 'corporate', or 'personal', rather than

2 E. Nimni, 'The conceptual challenge of non-territorial autonomy', in E. Nimni, A. Osipov and D. J. Smith (eds.), The Challenge of Non-territorial Autonomy: Theory and Practice (Peter Land, Oxford, 2013) p. 13 .

3 W. Kymlicka, 'National cultural autonomy and international minority rights norms', 6:3 Ethnopolitics (2007) pp. 379-393.

4 F. Prina, 'Nonterritorial Autonomy and Minority (Dis) Empowerment: Past, Present, and Future', Nationalities Papers (2020) p. 2. 
territorial. It aspires to facilitate minority self-government without offending the territorial interests of competing collective peoples.

Of course, NTA is seldom touted as a thoroughgoing political solution. It is not intended to provide exhaustive, state-like authority. Rather, it is a way to govern certain functional domains. ${ }^{5}$ Those domains cannot be territorial they cannot be place-based, nor related to finite physical resources. To put it another way, they cannot be zero-sum. This eliminates authority over lands, mining, fish and wildlife, infrastructure, and energy. Also eliminated are inherently state-level portfolios: defence, border-control, foreign policy, monetary policy, and so forth. Still, this leaves to NTA a wealth of potential responsibilities. De Villiers enumerates several: "education; promotion of language; culture; art, music and literature; historic and festival days; museums; symbols and insignia; place names; sport and recreation; ... and media". 6 To these one might add health, welfare, economic development, family law, customary law, and religion.

NTA has a long and respected pedigree. Historically the most famous NTA arrangement was the Ottoman Empire's Millet System, under which Jews and Christians, along with the Muslim majority, governed their respective cultural communities in keeping with their religious doctrines. ${ }^{7}$ Later, another variety of NTA, 'national personal autonomy', was famously championed by Austrian political scientists Karl Renner and Otto Bauer as a tool for the Hapsburg Empire to quell infighting among its intermixed cultural communities. ${ }^{8}$ Renner and Bauer proposed that the sort of governance typically exercised by nationstates could be exercised by cultural nations alone. Citizenship in a cultural nation would be analogous to membership in a religious denomination - "a personal association of those sharing a way of thinking and speaking." ${ }^{9}$ As with "separation of church and state", nation and state would be rigorously distinct.

While Renner and Bauer's "Austrian solution"10 was never implemented, other versions of NTA have more recently come to fruition, in places as diverse

5 J. Coakley, 'Introduction: Dispersed minorities and non-territorial autonomy', 15:1 Ethnopolitics (2016) pp. 1-23.

6 B. de Villiers, 'Self-Determination for Aboriginal and Torres Strait Islander people: Is the answer outside the territorial square?', 16 University of Notre Dame Australia Law Review (2014) p. 103.

$7 \quad$ K. Barkley and G. Gavrilis, 'The Ottoman Millet System: Non-territorial autonomy and its contemporary legacy', 15:1 Ethnopolitics (2016) pp. 24-42.

8 Coakley, supra note 5.

9 K. Renner, 'State and nation', in E. Nimni (ed.), National-Cultural Autonomy and its Contemporary Critics (Routledge, London, 2004) p. 3 o.

10 T. Nieguth, 'An Austrian solution for Canada? Problems and possibilities of national cultural autonomy', 42:1 Canadian Journal of Political Science (2009) pp. 1-16. 
as Canada, ${ }^{11}$ numerous Central and Eastern European states, ${ }^{12}$ and, perhaps most famously, in Belgium's bicultural Brussels-Capital region. ${ }^{13}$ Also, as we will now show, NTA has been championed by some as a pathway for the self-determination of one of the most common, and vexingly situated, internal minorities, Indigenous peoples.

\subsection{Minority Nations and Indigenous Peoples}

Will Kymlicka, in his pathbreaking Multicultural Citizenship, ${ }^{14}$ suggests the world's numerous "minority nations" can be divided into two classes. One class are Indigenous peoples. Having long been incorporated into, and marginalised by, dominant states, Indigenous peoples around the world now press for self-determination - for authority over matters key to their cultural survival, including language, spirituality, customary law, land and resources. In this way, Indigenous peoples are not unlike Kymlicka's second class of minority nations, which he calls "stateless nations". These include Quebecois, Åland Islanders, Catalans, Kurds, and so forth. Like Indigenous peoples, these nations lack states of their own, instead existing as sub-state peoples, often with a history and/or ongoing experience of cultural oppression and political domination at the hands of the majority.

Given the similarities between Indigenous peoples and other minority nations, it is no wonder their paths toward self-determination can also appear similar. In the spirit of the decolonised peoples of Africa and South Asia, Indigenous peoples may occasionally seek statehood - a goal that appears promising for the Inuit of Greenland. Or, like Åland Islanders, Indigenous peoples may be granted de facto control of purpose-built subunits - for example, Canada's Nunavut Territory. Another option may be power sharing, exercised in various ways. Like with the minority Serb and Italian communities in Croatia, the Maori of New Zealand enjoy a fixed share of seats in parliament. And, as with the various minority ethno-religious communities in Lebanon, Indigenous Fijians for a time exercised shared rule through consociationalism. ${ }^{15}$

S. Chouinard, 'The rise of non-territorial autonomy in Canada: Towards a doctrine of institutional completeness in the domain of minority language rights', 13:2 Ethnopolitics (2013) pp. 141-158.

B. Dobos, 'The elections to nonterritorial autonomies of Central and South Eastern Europe,' Nationalities Papers (2019) pp. 1-18. Coakley, supra note 5 .

14 W. Kymlicka, Multicultural Citizenship: A Liberal Theory of Minority Rights (Clarendon Press, Oxford, 1995). 
And yet, for all their similarities, Indigenous peoples clearly differ from other minority nations. For the purposes of this article, at least four differences are salient. The first has to do with their respective demographic positions. Unlike, for example, Quebecois, who comprise a decisive majority of the population in their homeland, almost all Indigenous peoples have been expelled from, or overwhelmed within, their traditional territories. Only in remote regions, such as the Arctic and Amazon, do Indigenous peoples still numerically dominate.

A second difference of Indigenous people concerns how they became minorities in the first place. Minority nations like the Quebecois were annexed for economic or strategic motives - because exogenous regimes benefitted from controlling the minority's region, wealth, or population. Often these benefits have faded with time. Indigenous peoples, however, were absorbed for a more enduring reason - settler-colonialism. As famously theorised by Wolfe, settler-colonialism is driven by the land-hunger of settlers. ${ }^{16}$ These settlers invade Indigenous territories, dispossess the inhabitants, sink their own roots in the soil, and nurture new versions of the European motherland. As Wolfe states, "settler colonizers come to stay". ${ }^{17}$ Occupying Indigenous land is the whole point of their project.

Having been both overwhelmed and dispossessed, Indigenous peoples find themselves differently situated than other minority nations in a third way. They are especially culturally vulnerable. Whereas Quebec, for instance, enjoys a robust Francophone culture, most Indigenous cultures are in peril. Settlers discouraged or prohibited many Indigenous traditions, such as potlatches, shamanism, and drum-dancing. Indigenous lifeways and languages were repressed. For example, today in Canada only 17 per cent of Indigenous people can converse in their mother tongue. ${ }^{18}$ At least 10 of Canada's Indigenous languages have gone extinct in the past century, and of the 70 that remain, all but three are endangered. ${ }^{19}$

16 P. Wolfe, 'Settler Colonialism and the elimination of the native', 8:4 Journal of Genocide Research (2006) pp. 387-409.

17 Ibid., p. 338.

18 T. McCarty, 'Policy and politics of language revitalization in the USA and Canada,' in S. Coronel-Molina and T. McCarty (eds.), Indigenous Language Revitalization in the Americas (Routledge, London, 2016).

19 O. McIvor and A. Anisman, 'Keeping our languages alive: Strategies for Indigenous language revitalization and maintenance', in Y. Watanabe (ed.), Handbook of Cultural Security (Elgar, London, 2018) p. 9 . 
There is a final way Indigenous groups are unlike other minority nations. Kymlicka defines "stateless" minority nations as peoples who lost out in the battle for modern statehood ${ }^{20}$ - peoples who did, or do, have the desire and capacity to become Westphalian sovereigns. Quebec, Catalan, and Scotland, for example, have each contemplated joining the global family of states, with all that entails, including hard borders, territorial jurisdiction, and exclusive citizenship. Contrarily, most Indigenous groups do not aspire to statehood. Often, their ambitions are for almost the opposite - for a revival of their pre-contact agency, values and traditions. These goals are non-Westphalian.

\subsection{Indigenous Peoples and NTA}

For all four of the above reasons, Indigenous peoples, even more than other minority nations, may be good candidates for NTA. As noted, Indigenous peoples, having been 'swamped' by settlers, seldom form the sort of regional majorities required for territorial solutions such as empowerment within federal subunits. Indigenous territorial authority is further stymied by settlers' historic and enduring attachment to land: for Indigenous peoples to regain their territory, settlers - who have quite literally grounded their economies and societies in that territory - would have to give it up. At the same time, many of the most pressing Indigenous issues relate to cultural and linguistic vulnerability, the precise functional domains best addressed by NTA. Finally, as just noted, unlike 'stateless' minority nations, many Indigenous peoples do not desire anything like Westphalian statehood.

Hence, certain thinkers have called for Indigenous peoples to be granted NTA. According to de Villiers, "If ever there was a group for which a nonterritorial solution for self-determination is to be found it is Aboriginal people". ${ }^{21}$ Klímová-Alexander agrees: "I believe that nonterritorial autonomy, which allows for the enjoyment of cultural and economic rights over Indigenous territories, offers a better, more universally applicable and less conflict-prone solution for Indigenous peoples worldwide". ${ }^{22}$ Nimni concurs: "The model proposed by Renner and Bauer is well suited to minorities that demand significant autonomy but for a variety of reasons cannot have separate states. A prime example of such minorities is Indigenous peoples." 23

\footnotetext{
20 W. Kymlicka, 'Theorizing Indigenous Rights', 49:2 University of Toronto Law Journal (1999) p. 282.

21 De Villiers, supra note 6, p. 94.

22 I. Klímová-Alexander, 'Transnational Romani and indigenous non-territorial selfdetermination claims', 6:3 Ethnopolitics (2007) p. 397.

23 Nimni (ed.), supra note 9, p. 11.
} 
And indeed, NTA is being experimented with in numerous Indigenous contexts. In Canada, NTA is a common component of Indigenous self-government regimes. For example, Nieguth notes that the Nisga'a Nation government "includes a significant extra-territorial element, as it extends ... to members of the Nisga'a nation that reside outside the nation's territory". ${ }^{24}$ In New Zealand, NTA is exercised by Urban Maori Authorities. ${ }^{25}$ In the 'Plurinational State of Bolivia', Indigenous NTA is etched in the constitution. ${ }^{26}$ In Ethiopia, NTA has been used in an attempt to empower Indigenous peoples in the region of Benishangul Gumuz. ${ }^{27}$ And in the most cited examples of Indigenous NTA, ${ }^{28}$ Europe's Nordic countries have all established Sami assemblies.

Yet faith in Indigenous NTA is not universal. This is for another reason seen to distinguish Indigenous peoples from others: their singular relationship to the land ${ }^{29}$ While Renner defended NTA by stating, "There is no necessary connection between the consciousness of nationality and a particular territory",30 Indigenous peoples would likely disagree. So too would anthropologists such as Brody, ${ }^{31}$ who divide the world's peoples into two dichotomous types. One type are agrarian-industrialists, who thrive by manipulating whatever environment they find themselves in. Their lifeways are portable and often land-hungry; since the Agrarian Revolution, they have expanded to dominate the world. The other type of peoples are Indigenes, mostly rooted in hunter-gathering,

24 Nieguth, supra note 10, p. 8.

25 P. Patton, 'National autonomy and Indigenous sovereignty', in Nimni (ed.), supra note 9; Coakley, supra note 5 .

26 I. Radhuber, 'Indigenous struggles for a plurinational state: An analysis of indigenous rights and competences in Bolivia, 11:2 Journal of Latin American Geography (2012) p. 167; Nimni, supra note 2.

27 B. Dessalegn, 'Experimenting with non-territorial autonomy: Indigenous councils in Ethiopia', 18:2 Journal of Ethnopolitics and Minority Issues in Europe (2019) pp. 3-23.

28 See e.g., S. Tuulentie, "Culture alone will not put bread on the table". The many facets of the debate on the preservation of Sami culture', 16:1 Acta Borealia (1999) pp. 97-115; M. Amarjeet Singh, 'Ethnic diversity, autonomy, and territoriality in Northeast India: A case of tribal autonomy in Assam', 32:6 Strategic Analysis (2008) pp. 1101-1114; B. de Villiers, 'Protecting minorities on a non-territorial basis - recent international developments', 3:4 Beijing Law Review (2012) pp. 170-183; E. Josefsen, U. Mörkenstam and J. Saglie, 'Different Institutions within Similar States: The Norwegian and Swedish Sámediggis', 14:1 Ethnopolitics (2015) pp. 32-51; T. Malloy, A. Osipov and B. Vizi (eds.), Managing Diversity through Non-territorial Autonomy: Assessing Advantages, Deficiencies, and Risks (Oxford University Press, Oxford, 2015).

29 L. Betasamosake Simpson, 'Land as pedagogy: Nishnaabeg intelligence and rebellious transformation', 3:3 Decolonization: Indigeneity, Education \& Society (2014) pp. 1-25.

$30 \quad$ Renner, supra note 9, p. 25.

$3^{1}$ H. Brody, The Other Side of Eden: Hunter-Gatherers, Farmers, and the Shaping of the World (Douglas and McIntyre, Vancouver, 2001). 
whose well-being has hinged on adapting to their particular environment. Indigenous peoples were grounded, economically and cosmologically, in some specific place. Now they have almost no place left. Thus, for Indigenous peoples, protecting their land and resources is paramount.

Hence, some scholars argue NTA is distinctly insufficient for securing Indigenous self-rule. As Nieguth observes, "national cultural autonomy has little to say on the nexus between land claims, national self-government, and collective identity that underpins much of Aboriginal nationalism". ${ }^{32}$ Kymlicka seems to agree, suggesting that in at least some cases Indigenous NTA is being promoted not to fulfil but rather sidestep Indigenous territorial objectives. ${ }^{33}$ Patton, commenting on Renner and Bauer's model of NTA, is similarly damning: "The experience of colonized Indigenous peoples suggests that control over land and resources is fundamental to their capacity to survive as autonomous nations within former colonial states". ${ }^{34}$

Who is right? Are de Villiers, Klímová-Alexander and Nimni correct that NTA arrangements are ideally suited for Indigenous circumstances? Or, conversely, are Nieguth, Kymlicka and Patton correct - is NTA woefully inadequate for, or even a distraction from, Indigenous demands? In this paper we set out to explore that question by studying the case of Norway's Sami people. Though Sami are also resident in Russia, Finland and Sweden, it is in Norway where they are most populous as well as most politically empowered. For three decades Norway's Sami have exercised an increasing degree of authority by way of a Sami assembly, or Sámediggi, and have come to enjoy a host of Sami-specific rights. As noted, this authority, and these rights, are frequently cited as an exemplar of NTA. We seek to discern the extent, trends, motives, and barriers to the use of NTA by Norway's Sami. We do this to determine whether, why, and how NTA has facilitated Sami self-determination, and what this says about its utility for Indigenous peoples.

Speakers of a Finno-Ugric language, the Sami have inhabited northern Fennoscandia since ancient times, living until recently as nomadic hunters, fishers, and reindeer herders. Beginning more than 500 years ago they were absorbed into southerly kingdoms, including the Danish-Norwegian kingdom,

\footnotetext{
$32 \quad$ Nieguth, supra note 10, pp. 10-11.

33 Kymlicka, supra note 3, p. 39 o.

34 Patton, supra note 25, p. 115.
} 
through a protracted and largely non-violent process of cultural synthesis and colonisation. Sami joined coastal trade networks, adopted Norwegian agricultural practices, were proselytised by Christian missionaries, and were taxed by foreign kings. As nomads they were denied property ownership; ${ }^{35}$ the wild lands used by Sami became "King's ground" ${ }^{36}$ Meanwhile, the Danish throne encouraged agrarian homesteading of Sami lands, both by Norwegian settlers and by Sami. ${ }^{37}$

When Norway became independent from Denmark in 1814, Sami were considered full citizens. ${ }^{38}$ Unlike in New World states such as the U.S. and Canada, in Norway there was no native legal status or tribal recognition. ${ }^{39}$ Sami were thus spared common settler-colonial injustices such as disenfranchisement and confinement on reserves. At the same time, Sami never got the opportunity to sign treaties securing their political and territorial distinctiveness. ${ }^{40}$ For good or ill they were, by law, Norwegians.

In practice, however, Sami were treated as different. One way was to their advantage. In northern Norway, the practice of reindeer herding was (and remains) open only to Sami. The provenance of this right is unclear but is considered 'ancient'.41 But in many other ways, Sami were disadvantaged. Due to perceptions of Sami genetic and cultural inferiority, ${ }^{42}$ the homogenising impulse of Norwegian nation-building, and humanitarian and religious desires to lift Sami from their 'backwards and wretched' state, Sami were subjected to the state policy of fornorsking, or Norwegianisation.

35 C. Allard, 'The Nordic countries' law on Sámi territorial rights', 2:2 Arctic Review on Law and Politics (2011) pp. 159-183.

36 A. Sandberg, 'Collective rights in a modernizing North - on institutionalizing Sami and local rights to land and water in northern Norway', 2:2 International Journal of the Commons (2008) pp. 269-287

37 Sandberg, ibid.

$38 \quad$ G. Wilson and P. Selle, 'Indigenous Self-Determination in Northern Canada and Norway', 69 IRPP Study (Institute for Research on Public Policy, Montreal, 2019).

39 An exception with symbolic, but no legal, significance is the $175^{1}$ Lapp Codicil, struck between the Danish/Norwegian and Swedish/Finnish kingdoms, addressing Sami transborder herding. See A. Sandberg, 'Collective rights in a modernizing North', 2:2 International Journal of the Commons (2008) pp. 269-287.

40 C. Allard, "The rationale for the duty to consult Indigenous peoples: Comparative reflections from Nordic and Canadian legal contexts', 9 Arctic Review on Law and Politics (2018) pp. $25-43$.

$41 \quad$ Sandberg, supra note 36.

42 Josefsen et al., supra note 28. 
Norwegianisation lasted from the 1870s until at least the Second World War. ${ }^{43}$ During this period, Sami cultural manifestations, such as traditional gákti clothing and joik singing, were discouraged. In much of Norway, settlers were permitted and even encouraged to expand into lands used by Sami. Sami were denied land-ownership unless they displayed fluency in, and active use of, Norwegian. ${ }^{44}$ Sami children were educated solely in Norwegian, sometimes in assimilative and abusive residential schools. ${ }^{45}$ In general, ethnic Norwegians looked down on Sami and were sometimes openly discriminatory. Unsurprisingly, the number of people admitting or even perceiving themselves to be Sami plunged. ${ }^{46}$ Likewise, especially in the coastal, or 'outer', north, use of the Sami language dramatically declined. ${ }^{47}$

After the Second World War, overt Norwegianisation ended - and yet, in some ways, Sami assimilation accelerated. Due to post-war rebuilding after the Nazi devastation of northern Norway, to advances in transportation and communications, and to dramatic expansion of the Norwegian welfare state, Sami were ineluctably drawn into mainstream Norwegian society. Discriminatory treatment diminished, though did not disappear. Sami became, in effect, "Sami-speaking Norwegians" 48 - they were seen as backward and strange, perhaps, but deserving of basic equality. During the post-war period, Sami came to advance their distinct cultural concerns as one of scores of interest groups active in Norwegian civil society, using electoral and other channels to press for attention and funds from the state.

At the same time, Sami took their first cautious steps toward collective self-determination. In the late 1950s, a committee comprising Sami and state authorities proposed creating a distinct legal district in which the Sami language would enjoy preferential treatment. ${ }^{49}$ The district would be in Finnmark, Norway's northernmost and largest county, where Sami are most numerous.

43 P. Selle, A. Semb, K. Strømsnes, and Å. Nordø, Den samiske medborgeren (Cappelen Damm Akademisk, Oslo, 2015).

44 A. Semb, 'From "Norwegian citizens" via "citizens plus" to "dual political membership"'?, 35:9 Ethnic and Racial Studies (2012) pp. 1654-1672.

H. Minde, 'Assimilation of the Sami: Implementation and consequences', 20:2 Acta Borealia (2003) pp. 121-146.

46 T. Falch, P. Selle and K. Strømsnes, 'The Sámi: 25 Years of Indigenous Authority in Norway', 15:1 Ethnopolitics (2016) pp. 125-143.

47 E. Eypórsson, Sjøsamene og kampen om fjordressursene (CálliidLágádus, Karasjok, 2008).

48 Falch et al., supra note 46.

49 I. Bjørklund, 'Påskeresolusjonen i 196o - Karasjoks etnopolitiske oppgjør', 48:3 Heimen - Lokal og regional historie (2011) pp. 195-206; A. Andresen, 'Vitenskapene og den nye samepolitikken (1945-1963)', 95:3 Historisk Tidsskrift (2016) pp. 405-435. 
However, political opponents, among them many Sami, feared this would establish a 'Sami reservation'. The plan was never implemented. Nonetheless, in the 1970s Sami activists popularised the geographic concept of Sápmi, an area approximating the extent of historic Sami habitation. Though the boundaries of Sápmi were never formalised, most Sami maps depict it extending across much of Fennoscandia, including the northern two-thirds of Norway. There were other acts of nation-building, too: a Sami flag and national day were adopted, as was a Sami anthem, celebrating Sámieanan, the Sami homeland. ${ }^{50}$

At the end of the 1970 s came a "critical juncture",51 the so-called Alta Conflict. ${ }^{2}$ The conflict erupted when Norway announced plans to dam the Alta River in inner Finnmark, disrupting the salmon run, flooding reindeer pasturelands, and displacing the Sami village of Masi. Between 1979 and 1981, Sami, along with environmentalists, vigorously protested, conducting hunger strikes, occupying the prime minister's office, appealing to the European Commission of Human Rights, ${ }^{53}$ and blockading the dam construction site. At one point, 10 per cent of Norway's police force was on guard in Finnmark. ${ }^{54}$ The conflict was the most disruptive event of civil disobedience in modern Norway. ${ }^{55}$ Suddenly a substantial portion of Sami demanded not mere integration but accommodation as a distinct, rights-bearing Indigenous nation. They pressed to be not just included in Norwegian politics but to have a new space alongside it, where they could self-determine.

Norway, caught off guard by the Alta Conflict and fearing for its reputation as a champion of human rights, scrambled to accommodate certain of the Sami demands. ${ }^{56}$ In short order a Sami Rights Commission was empanelled, and by the end of the 1980s the foundational Sami protections were in place - the 'Sami clause' of the Norwegian constitution, the signing of the International

5o T. Falch and P. Selle, Sametinget - institusjonalisering av en ny samepolitikk (Gyldendal Akademisk, Oslo, 2018).

$51 \quad$ S. Lipset and S. Rokkan, Party Systems and Voter Alignments: Cross-national Perspectives (Free Press, New York, 1967).

$5^{2}$ H. Eidheim, 'Ethno-political development among the Sami after World War II: The invention of selfhood', in H. Gaski (ed.), Sami Culture in a New Era: The Norwegian Sami Experience (University of Washington Press, Seattle, 1997).

53 ECommHR case of $G$ and $E v$. Norway (Eur.Comm.HR, 3 October 1983, 35 D\&R 30).

54 A. Andersen and A. Midttun, 'Conflict and local mobilization: the Alta hydropower project', 28:4 Acta Sociologica (1985) pp. 317-335.

55 K. Strømsnes and P. Selle, 'Aksjoner i det representative demokrati' in H. Narud, K. Heidar and T. Grønlie (eds.), Stortingets historie 1964-2014 (Fagbokforlaget, Bergen, 2014).

56 H. Vik, H. Hagtvedt and A. Semb, 'Who owns the land? Norway, the Sami and the ILO Indigenous and Tribal Peoples Convention', 20:4 International Journal on Minority and Group Rights (2013) pp. 517-550; Josefsen et al., supra note 28. 
Labour Organization's Convention on the Rights of Indigenous and Tribal Peoples (ILO 169), and the Norwegian Parliament's Sami Act. Flowing from these protections, Norway in 1987 established Europe's first contemporary Indigenous political body, the Sámediggi, which became the core Sami institution both politically and symbolically. For Norway, a country with a political tradition of unitary government and universal citizenship, and a history of Sami assimilation and discrimination, these were remarkable steps. They were not, however, steps toward Sami territorial authority.

Though the Alta Conflict had been about land and resources, pitting Sami land-use practices against the development goals of the state, accommodating Sami territorial interests was at the time considered unrealistic. This was due largely to ethnogeography. In most of Norway, Norwegians live side by side with Sami, and dramatically outnumber them. Sami today are numerically dominant only in inner Finnmark. There they form clear majorities in two municipal districts, Kautokeino and Karasjok, and bare- or near-majorities in three more municipal districts, Tana, Nesseby and Porsanger. Moreover, because of extensive intermarriage, assimilation, and, at least in the past, suppression of Sami heritage, being Sami is seldom "a matter of either/or". ${ }^{57}$ Rather, many people think of themselves as part-Sami, or identify as Sami only at certain times or places, or, despite possessing clear Sami heritage, identify solely as Norwegian.

For all these reasons, despite Norway's desire to appease Sami in the aftermath of the Alta Conflict, there seemed to be no clear, substantial territory over which Sami could be granted control. This was precisely the sort of challenge that inspired the advent of NTA - the problem of multiple, clashing peoples occupying the same limited place. Hence, Sami were initially empowered in a way that decoupled people and place. In short order they became the world's most prominent Indigenous group exercising NTA.

In this section we discuss the establishment and scope of Norwegian Sami NTA. This NTA applies to a wide range of functional domains, including political participation, language, economic development, and cultural-heritage management. These NTA functional domains are all administered by the Sámediggi. None involve territorial powers - jurisdiction, land management, 
or regulation of physical access. Put another way, Sami NTA is not zero-sum: it does not intrude on the rights or powers of non-Sami.

Since the birth of the Sámediggi in 1987, key Sami democratic rights, such as political status, voting, and representation, have applied to all Norwegian Sami, whether they are reindeer herders in Kautokeino, surgeons in Hammerfest, or bureaucrats in Oslo. Sami political status is acquired by joining the Sami electoral registry. To join the registry, a person must confirm two things - first, that one feels Sami, and second, that one speaks Sami or grew up with at least one Sami-speaking parent, grandparent or great-grandparent. When the registry was instituted in the late 198 os its enrolment was around 5,500. Today that number has grown to 18,000 , most dwelling in the north but others hailing from every other corner of Norway.

Being enrolled in the Sami registry is a precondition for enjoying two other core Sami democratic rights, voting and representation. Only registered Sami can cast ballots in Sámediggi elections. The Sámediggi's 39 representatives are chosen from seven electoral districts that together cover all of Norway. The Sámediggi is tasked under the Sami Act with representing Sami in all regions of Norway, and with dealing with all matters particularly affecting Sami. ${ }^{58}$ Originally its role was largely advisory, counselling and critiquing the Norwegian government on Sami-related matters. Over the years it has become more like a co-decider. Also, the Sámediggi was originally tasked with administrating Norwegian-government programs using earmarked funds. Now, the Sámediggi makes many of its own administrative and funding decisions, drawing on an annual budget of around NOK 520 million (USD 57 million).

Second only to facilitating Sami political participation, the Sámediggi's most important functional domain is promoting the Sami language. In 1992 the Sami Language Act granted all Sami children the right be taught the Sami language in school. Moreover, where at least 10 Sami children request it, the Sami language must be made their general language of instruction in school. ${ }^{59}$ Hence, even in Oslo there are schools that deliver the curriculum in the Sami language. Additional Sami language rights apply in what is called the Sami Language Administrative District, ${ }^{60}$ covering 12 municipalities with a large Sami population. In the district, Sami is an official state language on a par with Norwegian. All students there can choose either Sami or Norwegian as their general language of instruction. As well, in this district Sami have the right to interact with government agencies in the Sami language.

$5^{8} \quad$ Wilson and Selle, supra note 38.

$59 \quad$ Falch et al., supra note 46.

6o Wilson and Selle, supra note 38, p. 36 . 
A third important NTA functional domain is Sami-oriented economic development, fostered through the Sámediggi's business-incentive grant scheme. The scheme pre-dates the Alta Conflict, having been instituted by the Norwegian government in 1974. Today grants are available to applicants in 21 municipal districts and parts of 10 others. For certain grants, such as for practising doudji (Sami traditional crafts), applicants must meet the criteria for enrolment in the Sami electoral registry. ${ }^{61}$ For other grants even non-Sami may qualify, as long as their business is perceived to benefit Sami.

A fourth Sámediggi NTA functional domain is cultural-heritage management. This responsibility does not in practice extend throughout Norway, but instead is "limited to the territories in which the Sami currently practice reindeer husbandry and historically have exploited other resources".62 As will be discussed later, these reindeer-herding territories cover approximately the northern 40 per cent of Norway.

In addition to these early applications of Sami NTA, Norway in 2005 struck an agreement with the Sámediggi to consult Sami on all governmental decisions likely to affect them. ${ }^{63}$ On many matters, such as culture, language, education and spirituality, this consultation requirement applies to Sami everywhere in Norway.

\subsection{Sami Territorial Authority}

As shown above, Sami NTA in Norway is extensive. For this reason, Sami authority has been characterised as an exemplar of NTA, showcasing how dissevering 'blood' from 'soil' can satisfy the political ambitions of Indigenous peoples. We suggest, however, that it may be time to reconsider that characterisation. Sami territorial authority has in fact been on the rise. In a few instances, this newfound territorial authority is exercised by the Sámediggi, but in most cases it is exercised by other de jure or de facto Sami entities.

As noted previously, territorial authority describes any one of three sorts of zero-sum powers - jurisdiction, land-use management, and regulation of access to land and resources. In the case of Norway's Sami, the least common of these forms of territorial authority is the first, jurisdiction. In no region of Norway do Sami enjoy explicit legal jurisdiction. However, in certain cases Sami do wield de facto control. Such cases are limited to the few aforementioned Finnmark municipal districts where Sami form a local majority. In these districts, Sami, by dint of their numbers, democratically dominate the public

\footnotetext{
$61 \quad$ Falch et al., supra note 46, p 133.

62 Falch et al., ibid.

63 Allard, supra note 40.
} 
municipal governments. Of course, the law-making and law-enforcement powers of these municipal governments are somewhat limited - not the extensive jurisdiction envisioned by most proponents of Indigenous self-rule.

A far more substantive Sami territorial power relates to selective access to lands and resources - in this case, the right of Sami to use certain lands and resources in ways denied to non-Sami. Falling into this category is the oldest, most iconic Sami territorial right, reindeer herding. As noted, the Sami 'reindeer-herding right' has been honoured in Norway for centuries. This right is geographically limited to the north of the country, covering about 40 per cent of Norway's land mass. ${ }^{64}$ Approximately 3,000 Sami are involved in herding, owning some 200,000 reindeer. ${ }^{65}$ For several reasons, herding is officially outside the scope of authority of the Sámediggi. Instead, authority over reindeer herding is exercised by Norway's Ministry of Agriculture, in collaboration with the Sami Reindeer Herders Association. However, over the past decade the Sámediggi has gained increased authority over reindeer-related matters, such as managing grazing-lands and reviewing development proposals that might impact herding.

Falling into a similar category are Sami fishing rights, instituted in 2012. In Finnmark as well as parts of Troms and Nordland counties, small fishing vessels now enjoy certain privileges, including a 'bonus' fishing quota and exclusive rights to fish in inshore waters. Traditionally these small vessels have been predominantly owned and operated by Sami. Hence, these fishing rights, unlike reindeer-herding rights, are targeted at, but not legally exclusive to, Sami. The Sámediggi, in collaboration with Norwegian authorities, plays a part in managing this fishery. ${ }^{66}$

The final sort of Sami territorial authority, and certainly the sort that has expanded most dramatically of late, is Sami collective ownership and management of land and resources. The first Sami victories in this regard were achieved through the courts. Two cases, both from 2001, are notable. In the so-called Svartskog case, the Norwegian High Court ruled that a predominantly Sami

\footnotetext{
$64 \quad$ Wilson and Selle, supra note 38, p. 37.

65 J. Riseth, J. Åge and I. Lie, 'Reindrifta i Finnmarks betydning for næringsutvikling og samfunnsutvikling', in E. Angell, S. Eikeland and P. Selle (eds.), Nordområdene i endring. Urfolkspolitikk og utvikling (Gyldendal Akademisk, Oslo, 2016).

66 S. Andersen and E. Eypórsson, 'Kystfiskeutvalget - Drømmen som brast?', in B. Bjerkli and P. Selle (eds.), Samepolitikkens utvikling, (Gyldendal Akademisk, Oslo, 2015); B. Hersoug and E. Mikkelsen, 'Samisk fiske og sjøsamisk kultur - «fem på tolv» eller «fem over tolv»?', in Angell et al. (eds.), supra note 65 .
} 
community retained collective property rights to a local parcel of land despite claims of ownership by the state. ${ }^{67}$ Meanwhile, in Selbu, the High Court ruled a group of Sami reindeer herders have user rights, dating from "time immemorial", to graze their herds on local lands privately held by farmers. ${ }^{68}$ The very fact that these cases reached Norway's top court underscores their high stakes, with Sami winning territorial rights at what some perceived to be the expense of the Norwegian general public.

The courts have not been the only avenue through which Norway's Sami have enhanced territorial control. Such control has also been acquired through provisions of Norwegian legislation. An important example is the 2009 Planning and Building Act, with provisions that apply in the aforementioned Sami reindeer-grazing area. ${ }^{69}$ Those provisions allow the Sámediggi to raise objections to development that might negatively impact Sami. If the Sámediggi's concerns are not satisfied, development must cease until Norway's government either fixes the problem or overrides the Sami objection. ${ }^{70}$ Similarly, the aforementioned 2005 consultation agreement requires the Norwegian state to consult the Sámediggi (and sometimes other relevant Sami groups, such as reindeer herders) on all government undertakings affecting Sami. ${ }^{71}$ As noted, if those matters relate to culture or language they apply throughout Norway. If, however, they relate to land and natural resources, the state's duty to consult is geographically limited to "traditional Sami areas" - in principle, the 40 per cent of Norway where only Sami may herd reindeer.

But the most dramatic acquisition of Sami territorial authority was secured through negotiations with the Norwegian government. In 1997, Norway's Sami Rights Commission concluded Norway was in breach of Sami land-and-resource rights guaranteed under ILO 169. Some years later, formal consultations between Norway's Parliament and the Sámediggi commenced. These negotiations were unprecedented: They were conducted in the manner of "nation to nation" diplomacy, as if between two sovereigns, much like the "modern treaty" negotiations now common in Anglo-settler states such as Canada. While

67 M. Fitzmaurice, 'The new developments regarding the Saami peoples of the North', 16:1 International Journal on Minority and Group Rights (2009) pp. 67-156; B. Bjerkli, 'Svartskogen - en fortelling om motstand og forsvar av rettigheter', in G. Nilsen (ed.), Kulturmøter i Nord-Troms. Jubileumsbok for Nord-Troms museum 1978-2003 (Nord - Troms Museum, Sørkjosen, 2004).

68 Falch and Selle, supra note 5o.

$69 \quad$ Falch and Selle, ibid.

$70 \quad$ Wilson and Selle, supra note 38, p. 36.

71 Allard, supra note 40. 
Norway proposed that the state and the Sami co-manage disputed lands, the Sami additionally insisted that certain lands be returned directly to Indigenous owners. Eventually the negotiations produced the 2005 Finnmark Act.

The Finnmark Act applies, as the name suggests, only in Finnmark county again, the county with the greatest number of Sami. Among the institutions created by the act is the Finnmark Estate, or FeFo. FeFo is a co-management board tasked with overseeing Finnmark's common lands - approximately 95 per cent of the county. FeFo's board comprises three members appointed by the Finnmark County Council and three by the Sámediggi (one of whom must represent reindeer-herding interests). On some matters, super majoritarian voting rules ensure Sami concerns are overweighted in the Sami heartland of inner Finnmark. FeFo was at first wildly controversial, with detractors labelling it undemocratic and mounting a petition campaign to have it quashed. FeFo's actual effects have been less dramatic. ${ }^{72}$ While on one hand FeFo is mandated to manage Finnmark lands "in particular as a basis for Sami culture", it also must be "ethnically neutral", assigning rights and benefits to residents regardless of whether they are Sami, so long as doing so does not impair Sami culture.

A second institution created by the Finnmark Act is the Finnmark Commission. The commission is tasked with pursuing a sort of land claims settlement' by surveying Finnmark's vast commons - those lands overseen by FeFo - and assigning ownership and/or usage rights based on "prescription and immemorial usage".73 During the commission's first decade of work it for the most part surveyed outer Finnmark, assigning no collective land to Sami. This failure to provide explicit ownership to Sami alarmed the Sámediggi, the UN Special Rapporteur on the Rights of Indigenous Peoples, ${ }^{74}$ and various scholars, ${ }^{75}$ who suggested Norway remained in breach of ILO 169 .

Recently, however, the land-tenure situation in Finnmark appears to have changed markedly. In late 2019 the Finnmark Commission completed its survey of the lands of the inner Finnmark municipal district of Karasjok. At over

72 A. Spitzer and P. Selle, 'Claims-based co-management in Norway's Arctic? Examining Sami land governance as a case of treaty federalism', 52:4 Canadian Journal of Political Science (2019), pp. 723-741.

73 Fitzmaurice, supra note 67; Ø. Ravna and N. Bankes, 'Recognition of Indigenous land rights in Norway and Canada', 24:1 International Journal on Minority and Group Rights (2017) pp. $70-117$.

74 United Nations Human Rights Council, 'Report of the Special Rapporteur on the Rights of Indigenous Peoples on the human rights situation of the Sami people in the Sápmi region of Norway, Sweden and Finland' (2016).

75 E.g., Ø. Ravna, 'Sami rights to natural resources and lands in Norway', in N. Loukacheva (ed.), Polar Law and Resources (Nordic Council of Ministers, Copenhagen, 2015). 
5,0oo square kilometres, the Karasjok district is the second largest in Norway. It is also, as noted, a core Sami area, where reindeer herding is ubiquitous and where Sami comprise an overwhelming majority of the population. It was thus dramatic news when the commission declared almost all the land in Karasjok to belong not to the state but collectively to the local residents. Though the commission made little mention of the residents' ethnicity, it in effect assigned the land to the Sami. Even to Sami political insiders this was a surprising and welcome development. If it stands, ${ }^{76}$ the decision could be fairly characterised as Norway's (indeed, Europe's) first Indigenous land-claims settlement.

The Finnmark Commission's decision is also dramatic for what it means for the rest of the Sami heartland. The logic undergirding the decision suggests much more land will be turned over to the Sami. The commission observed that Karasjok had not been encompassed within Norway since "time immemorial", but rather was annexed in $175^{1}$ as part of a settlement with neighbouring Sweden. Since then, the commission ruled, the Norwegian state had not sufficiently established itself as the rightful owner of the area. As observers of the decision quickly noted, the same historical facts apply to Karasjok's even larger neighbour, the municipal district of Kautokeino, and to parts of the nearby Tana and Porsanger municipal districts as well. Hence it is now assumed the land in those districts, too, will be assigned to their overwhelmingly Sami populations. Barring reversals, this would result in Sami exercising collective ownership of an area of inner Finnmark exceeding 15,00o square kilometres, a territory larger than Montenegro or Qatar.

It can be seen, then, that over the four decades of Sami political mobilisation in Norway, there has been a clear trend concerning the exercise of Indigenous territorial authority vis-à-vis NTA.

After the Alta Conflict, when Sami shocked Norway with demands for recognition as a rights-bearing Indigenous nation, the powers they won were initially non-territorial. These initial Sami powers let them constitute, stand

76 At this point it is not completely certain the Karasjok decision will stand: various entities, including the Norwegian state, could contest it. Also, even if the decision stands, it is unclear what the practical consequences may be. Decisions will likely need to be made concerning governance of the newly assigned land. Will it continue to be governed by existing land-management authorities? Will it be governed by the public government of Karasjok? Or will governance be assigned to some other entity, such as, perhaps, the Sámediggi? Achieving clear answers will likely take several years. 
for office in, and be represented by, the Sámediggi. The Sámediggi was in turn empowered to manage functional domains relating to the Sami language, business development, cultural heritage, and the like.

These powers were a breakthrough in Sami self-determination. But they provided Sami with almost no authority over their traditional lands and resources. Securing such authority would have been difficult. This is in part because Sami are in a position common for Indigenous peoples: They have been overwhelmed in their homelands, minoritised by land-hungry settlers, rendered culturally vulnerable - and they have little desire for statelike status. These are the sorts of reasons that led de Villiers, Klímová-Alexander and Nimni to prescribe NTA as a means of Indigenous empowerment.

Yet as we have also shown, recent years have seen a shift. Though the early forms of Sami NTA remain in place, Sami have lately also acquired noteworthy territorial authority. This newest Sami authority is not limited to cultural, linguistic or spiritual matters. Rather, it is authority over lands and resources.

As mentioned, territorial authority is commonly seen as involving any one of three powers - jurisdiction, access control, and land-and-resource management. Sami now exercise all three. In the Sami-dominated municipal districts, they enjoy de facto jurisdiction (of an admittedly limited sort). They also enjoy privileged access to reindeer herding and certain fisheries. And, most notably, they have won a wide variety of rights concerning the regulation and ownership (or co-ownership) of their traditional lands. Save for the immemorial reindeer-herding right, these victories have come about in the past 15 years.

This Sami turn toward territorial authority is perhaps unsurprising. As noted, Sami identify as Indigenous peoples - peoples often defined by their distinctive economic and cosmological attachment to their lands. As also noted, Norway's modern era of Sami mobilisation arose from the Alta Conflict, a clash in the Sami heartland pitting Sami environmental concerns and traditional land-use practices against the development objectives of the state. Because of the nature of this clash, and because of Sami Indigeneity, Sami have sought and won greater control over territory - just as scholars such as Nieguth, Kymlicka and Patton might have predicted. We conclude that, while NTA has served Sami interests in Norway, it was insufficient to satisfy their distinctly Indigenous demands. Regaining control over territory has been core to the Sami campaign.

\subsection{Further Sami Territorialisation: Opportunities and Barriers}

Despite having achieved numerous territorial powers, the Sami of Norway have so far not consolidated these powers into anything like a comprehensive territorial regime. Instead, Sami powers over land-management, access to land 
and resources, and (very limited) jurisdiction apply to various zones and/or resources - here and there, to this and that. Moreover, these various zones and/ or resources are not overseen by a singular Sami authority but by a variety - by the Sámediggi, Sami-majority municipalities such as Karasjok, the Finnmark Estate, the Sami Reindeer Herders Association, and so forth. As a consequence, Sami exercise a sort of patchwork of territorial authority. There is no specific 'Sami Province' over which they comprehensively rule.

Theoretically, it is not impossible that the Sami might develop a comprehensive territorial regime. The apparent 'land-claim settlement' in Karasjok, especially, could provide Sami with political and geographic space in which to begin to develop their own semi-autonomous province. Such a province could be modelled on other regions of the world where Indigenes enjoy de facto or de jure self-rule, such as the aforementioned Nunavut Territory in Canada. We doubt, however, that such dramatic developments are likely. Indeed, far from establishing their own territorial regime, we suspect Norway's Sami have begun to encounter certain barriers that will slow and perhaps halt even relatively mundane territorialisation. We see three barriers as especially salient, relating to Norwegian and Sami demographics, Norway's constitutional structure, and political resistance.

First, further Sami territorialisation will be complicated by demography. Again, Sami are a minority outside inner Finnmark. It thus seems unlikely collective Sami land ownership will expand beyond inner Finnmark. Indeed, as noted, even Sami land co-management, currently spanning all of Finnmark, has been highly controversial. Meanwhile, despite 15 years of talk, Sami land co-management has not extended beyond Finnmark, to Nordland or Troms counties, which also are home to substantial Sami populations. At this point there is no reason to expect it will.

A second demographic factor likely to limit Sami territorialisation is urbanisation. ${ }^{77}$ Of late, enrolment in the Sami electoral registry has grown dramatically in cities outside the Sami core. This has been the case in northern cities like Tromsø and Alta, which in 2019 became the municipalities with the largest and third-largest number of Sami enrollees. It has also been the case far beyond Sápmi, in Oslo, now ranked fifth in enrolment. Such urbanisation is likely to continue. It is also likely to reduce the share of Sami with a political stake in exercising territorial authority, pointing in the direction of more NTA.

77 P. Selle, A. Semb and K. Strømsnes, 'Urbanisering av det samiske elektoratet: En framvoksende skillelinje i den moderne samepolitikken', Tidsskrift for samfunnsforskning (2020) pp. 101-123. 
Adding to the aforementioned demographic complications are limits placed on Sami territorialisation by Norway's constitutional structure. First, unlike settler-states such as the US and Canada, Norway is not a federal union of sovereign polities. Rather, it is unitary. Power has historically been concentrated in Oslo, making it hard for most Norwegians, including many Sami, to embrace the notion of sub-state actors wielding comprehensive territorial authority. At the same time, Norway has long devolved key decision-making and administrative responsibilities to its $35^{\circ}$ regional municipal districts, which jealously guard their power. Though, as noted, this tradition in effect provides Sami with public control in the municipal districts of inner Finnmark, it offers them little space within any given district to act in an explicitly ethnic dimension, and may hamper their collaboration across the districts of inner Finnmark. Moreover, beyond inner Finnmark it entrenches non-Sami authorities wary of ceding power to Sami.

Complicating matters more is Norway's long, proud history as a comprehensive welfare state. Norwegian culture is considered 'state friendly'. The role of the state is pervasive and thus universalising. There is little appetite for variations from region to region in the quantity and quality of state services such as transportation, medical care, and education. Hence, even remote, traditionally Sami areas broadly accept - even demand - inclusion in the welfare state, often valuing political and redistributive equality over ethnopolitical difference.

The Sami have also encountered non-structural political barriers to their further territorialisation. One of these barriers is the Sami's lack of revenue-generating power. Most territorial authorities, such as Norwegian municipal districts, Canadian provinces and even American Indian tribes, are empowered to raise funds by levying taxes or collecting resource revenues from development. The Sámediggi enjoys no such powers. Instead, it relies for all its funding on the Norwegian state. This limits the Sámediggi's capacity to exercise territorial authority, while also removing incentives for it to do so: if territorialisation incurs costs and challenges without benefits, why pursue it?

A final barrier to Sami territorialisation has been Norway's denial to the Sámediggi of other key territorial powers. Most notable was its refusal in the 2010 Minerals Act to allow the Sámediggi to veto mining projects or seek compensation in case of harm to Sami. This refusal was denounced by the Sámediggi, which deemed it a violation of ILO 169. The consequences of this decision were amplified in 2019, when Norway approved the first new mine in Finnmark in a generation. The mine is vigorously opposed by the Sámediggi, which calls it the gravest threat to Sami culture since the Alta Conflict. 
For all these reasons, barring some unforeseen change, Sami territorialisation in Norway is unlikely to go much further than it has already. Because of reasons common to Indigenous nations, Sami opportunities for exercising territorial authority are limited. At the same time, existing Sami territorial authority is unlikely to retreat. In part because of the Sami's distinctive, Indigenous attachment to their land, it is hardly surprising that, despite its nonterritorial start, Sami self-government in Norway has of late expanded beyond NTA, into substantial territorial authority. While NTA has been useful to Sami, it has proved insufficient. Territorial authority has been sought and, in a patchwork fashion, acquired - but the limits to such authority may be near. 